\title{
SPATIAL DISTRIBUTION OF INDOOR CONCENTRATIONS OF GREENHOUSE GASES AND AMMONIA IN A NATURALLY VENTILATED DAIRY BUILDING
}

\author{
M. Samer ${ }^{1}$ ， E. Abdelsalam², \\ J. M. El-Azab ${ }^{3}$ and K. M. Abdelbary ${ }^{1}$
}

ABSTRACT

Livestock buildings are a main source of gaseous emissions, such as ammonia ( $\left.\mathrm{NH}_{3}\right)$, methane $\left(\mathrm{CH}_{4}\right)$, carbon dioxide $\left(\mathrm{CO}_{2}\right)$, and nitrous oxide $\left(\mathrm{N}_{2} \mathrm{O}\right)$. Determination of spatial distribution of indoor gaseous concentrations is a particularly difficult task. Therefore, this study aims is investigation indoor concentrations of $\mathrm{NH}_{3}, \mathrm{CH}_{4}, \mathrm{CO}_{2}$, and $\mathrm{N}_{2} \mathrm{O}$ and analyzing their spatial distribution. Continuous measurements of indoor gaseous concentrations were carried out in a naturally ventilated dairy building. Ventilation rates were estimated and emission rates were quantified. Consequently, the results were compared with each other by performing correlation and regression analysis to develop the functions that estimate relationships among these gases. A multiple t-test was conducted for all gases to detect whether the indoor concentrations at different measuring points vary significantly from each other. Sensitivity analysis was conducted to assess the influence of the uncertainty of individual assumptions on the overall results of ventilation and emission rates. The results illustrated that spatial distribution of indoor gaseous concentrations is not uniform, where concentrations at the leeward side of the building were significantly higher than the concentrations at the windward side. The emissions factors were 1.8, 10.2, 351, and $0.1 \mathrm{~g} \mathrm{~h}^{-1} A U^{-1}$ for $\mathrm{NH}_{3}, \mathrm{CH}_{4}, \mathrm{CO}_{2}$, and $\mathrm{N}_{2} \mathrm{O}$, respectively.

Keywords: Spatial distribution, indoor air quality, air distribution, built environment, natural ventilation, greenhouse gases, ammonia, livestock buildings.

1 Associate Prof., Agric. Eng. Dept., Fac. of Agric., Cairo Univ., 12613 Giza, Egypt

2 Assistant Prof., Department of Laser Applications in Metrology, Photochemistry and Agriculture, National Institute of Laser Enhanced Sciences (NILES), Cairo University, 12613 Giza, Egypt

3 Associate Prof., Department of Engineering Applications of Lasers, National Institute of Laser Enhanced Sciences (NILES), Cairo University, 12613 Giza, Egypt. 


\section{INTRODUCTION}

griculture, with its two main parts plant and animal production,
is one of the main sources of greenhouse gases emissions and
the most important source of ammonia emissions. Animal production is a major source of atmospheric pollutants, such as: methane $\left(\mathrm{CH}_{4}\right)$, nitrogen oxides $\left(\mathrm{NO}_{\mathrm{x}}\right)$, carbon dioxide $\left(\mathrm{CO}_{2}\right)$ and ammonia $\left(\mathrm{NH}_{3}\right)$. Methane, nitrogen oxides and carbon dioxide are greenhouse gases (GHGs) that add to the global warming. Ammonia is responsible for eutrophication and soil acidification (Abdelbary et al. 2004; AbdelRahman et al. 2010; Abdel-Rahman et al. 2011; Samer, 2015). Animal production shares with $65 \%$ of the universal anthropogenic nitrous oxide $\left(\mathrm{N}_{2} \mathrm{O}\right)$ emissions and account for $75 \%$ to $80 \%$ of the emissions from agriculture. Enteric fermentation and manure management account for 35\% to $40 \%$ of the total anthropogenic methane $\left(\mathrm{CH}_{4}\right)$ emissions and $80 \%$ of $\mathrm{CH}_{4}$ emit from agriculture $(\boldsymbol{F A O}, 2006) . \mathrm{CH}_{4}$ and $\mathrm{N}_{2} \mathrm{O}$ are greenhouse gases (GHG) with Global Warming Potentials (GWP) of 23 and 296 times that of carbon dioxide $\left(\mathrm{CO}_{2}\right)$, respectively (IPCC, 2007). About $94 \%$ of global anthropogenic emissions of $\mathrm{NH}_{3}$ to the atmosphere arise from the agricultural sector of which close to $64 \%$ is associated with livestock management $(\boldsymbol{F A O}, 2006)$. Approximately, $75 \%$ of $\mathrm{NH}_{3}$ emissions come from livestock production (Reinhardt-Hanisch, 2008). Extravagant levels of $\mathrm{NH}_{3}$ emissions contribute to eutrophication and acidification of water, soils and ecosystems (Schuurkes and Mosello, 1988). In addition to the global warming potential of the greenhouse gases, ammonia emissions give a share in global warming when the ammonia is converted to nitrous oxide (Berg, 1999; Sommer et al., 2000).

Most of $\mathrm{CO}_{2}$ is created by the animals and exhaled by respiration. It can also be fraction of exhaust gases of heating systems being released in the barns. Additionally, a particular fraction of $\mathrm{CO}_{2}$ is released by the manure. The released $\mathrm{CO}_{2}$ from urine and dung in stored manure is less than $5 \%$ of the amount produced by respiration (Schneider, 1988). Low concentrations of $\mathrm{N}_{2} \mathrm{O}$ can be determined in dairy barns with liquid manure systems, where daily or recurrent manure removal into external storage tanks is applied and this does not make up a major source of $\mathrm{N}_{2} \mathrm{O}$ (Ngwabie et al., 2009). Hydrogen sulfide $\left(\mathrm{H}_{2} \mathrm{~S}\right)$ is classified as poison 
and causes death at $1000 \mathrm{mg} / \mathrm{L}$, where, in most situations, death occurs when opening the manure storages for manure removal (CIGR, 1994) and, therefore, all workers must leave the area for a while. Odors and dust/aerosols, there are increasing difficulties are expected in the near future where inconvenience and health-effects are inquiry. Manure management, inside and outside of livestock buildings, is in charge of emitting several air pollutants, such as: $\mathrm{CH}_{4}, \mathrm{~N}_{2} \mathrm{O}$ and $\mathrm{NH}_{3}$ (Samer, 2013). The factors-of-influence (FOI) that strongly affect the dispersion of $\mathrm{NH}_{3}$ are: $\mathrm{NH}_{3}$-mass-flow, internal and external temperatures, mean and turbulent wind components in horizontal and vertical directions, atmospheric stability, and exhaust air height where the continuous measurement of $\mathrm{NH}_{3}$ remains a difficult and costly project, in terms of capital investment, running costs or both (Von Bobrutzki et al., 2011). The determination of emission mass flow is essential not only to compute dispersal but also to develop reduction strategies. While husbandry, dunging, and feeding influence the indoor concentrations and emissions of harmful gases, the same for both forced ventilation and natural ventilation, the building envelope including ventilation openings (design and control) and the outside climatic conditions are the controlling influencing factors (Samer, 2011a,b,c; Samer and Abuarab, 2014). The highest average ammonia emission synchronizes with higher environmental temperature. The gaseous emissions from naturally ventilated cattle buildings significantly increase with air temperature (Morsing et al., 2008; Adviento-Borbe et al., 2010; Pereira et al., 2011). Low emission values can only be accomplished by reducing the emission source surfaces, decreasing temperature and air velocity near the source, minimizing airflow rates throughout the livestock buildings, and installing biofilters and bioscrubbers (BlanesVidal et al., 2007; Bjorneberg et al., 2009; Adviento-Borbe et al., 2010). Harmful gases emission flux drawing-off from a naturally ventilated building is dependent on wind velocity and turbulence fields inside and over the building envelope; therewith the emission mass flow is highly variable and difficult to estimate (Ngwabie et al., 2009; Van Buggenhout et al., 2009). The effects on indoor concentrations and emissions of harmful gases are as an outcome of changing airflow patterns and different types of flow in the boundary layer between slurry and ventilation air 
(Samer et al., 2011c). The ventilation rate and the gaseous emissions from a naturally ventilated livstock building are relying on wind velocity. In order to study air temperature and gaseous concentrations distribution all over the different zones of the building and to achieve an efficient control of the bio-responses, continuous observation and controlling of the micro-environment to variations of air velocity inside the building is required. Therefore, the air profiles should be examined and airflows should be analyzed through the building zones (Samer et al., 2011c). Large oscillations occur in ventilation rates estimated using the combined effects of wind pressure and temperature difference forces, owing to large oscillations in the wind velocity. The fluctuations of wind velocity negatively affect the estimation of ventilation rates and then the gaseous emissions (Samer et al., 2011a). Hence, the airflow profiles should be investigated and airflows should be analyzed in livestock barns. Studying the airflow profiles inside a livestock building is important to determine the air and pollutants distribution. Airflow patterns in animal buildings impact the distribution of air temperature, gas concentrations, and gases release from manure. Air velocity measurements have been used for airflow pattern measurements (Samer et al., 2011c). Gases emitted from animal houses are strongly related to airflow (Morsing et al., 2008).

The objectives of this study were: (1) investigating the indoor concentrations of $\mathrm{NH}_{3}, \mathrm{CH}_{4}, \mathrm{CO}_{2}$, and $\mathrm{N}_{2} \mathrm{O}$ and analyzing their spatial distribution, (2) deriving functions that estimate the relationships among these gases, (3) finding out whether the indoor concentrations at the different measurement points differ significantly from each other, and (4) quantifying the emissions factors of the gases under investigation.

\section{MATERIAL AND METHODS}

\section{Description of the investigated barn}

The investigated barn is surrounded by several agricultural buildings, except for the northern and western sides. Fortunately, the predominant winds are from the north and northwest. The dairy barn dimensions are $114 \times 36 \mathrm{~m}$, with roof height at the sidewalls of $3.5 \mathrm{~m}$ and $9 \mathrm{~m}$ at the gable peak, thus resulting in internal volume of the barn of $25,650 \mathrm{~m}^{3}$. The barn is designed to house 420 Holstein Friesian dairy cows (673 kg average body mass) in a loose housing system with freestalls. There is a manure 
channel with a depth of $2.34 \mathrm{~m}$ (manure depth was 0.7 to $1.2 \mathrm{~m}$ during the different experiments) under each cow pathway with a slotted floor, and there are four pathways, two on each side (the first is $3 \mathrm{~m}$ wide, and the second is $4 \mathrm{~m}$ wide). Manure removal procedure is performed when it reaches a depth of $1.8 \mathrm{~m}$. The total volume of the manure channels is $3750 \mathrm{~m}^{3}$, which is part of the barn volume, as the floor is slatted, subsequently, calculated barn volume is considered as $29,400 \mathrm{~m}^{3}$. Naturally ventilation by a draft introduced into the building through open sidewalls is used for the dairy barn under investigation, an open ridge slot, and open gates in the gable walls. Five ceiling fans are used to enhance the air distribution uniformity inside the barn for the duration of warm and hot periods. These fans are mounted to the ceiling along the building centerline and have a diameter of $6 \mathrm{~m}$.

\section{Experimental measurements}

Course measurements were conducted throughout three consecutive weeks in midseason. Exterior, interior air temperatures, relative humidity, wind velocity were recorded. Furthermore, aerial gases concentrations of $\mathrm{CH}_{4}, \mathrm{NH}_{3}, \mathrm{~N}_{2} \mathrm{O}$ and $\mathrm{CO}_{2}$ were continuously measured (1 minute interval) at 13 and 6 locations inside and outside the barn, respectively (Fig. 1). Temperature-humidity sensors (HX93AC, Omega Engineering, Stamford, Conn.) are used to carry out the measurements of temperature and relative humidity at 4 locations inside and at 1 location outside the barn (Fig. 1). These measurements were recorded every minute in order to notarize the indoor microenvironment of the livestock building. The ambient wind conditions were measured every minute with a weather station (Premium Weather Station, MEA, Magill, South Australia) located near the barn. The animal activity was measured using pedometers (AfiTag, Madero Dairy Systems Inc., Texas, USA). Two infrared photo-acoustic analyzers (1412, Innova AirTech Instruments, Ballerup, Denmark) are used to measure gaseous concentrations at 19 sampling points, with gas sampling duration of $1 \mathrm{~min}$ at each sampling point. Table 1 shows an overview of the instruments used to carry out the measurements inside and outside the investigated barn. Figs 1 and 2 show the design of the investigated dairy barn and the different measuring points. The red squares allocate the gas sampling points (MP) of the first multi-gas moni- 
tor, the blue squares specify the gas sampling points of the second multigas monitor, and the green squares label the temperature-humidity sensors (TFL). All instruments were placed at a height of $2.5 \mathrm{~m}$ to be unreachable by curious cows. Six external gas sampling points and one temperature-humidity sensor were located adjacent to the barn in order to sample the gases from fresh outdoor air as a reference for the indoor air and to measure the outdoor temperature and relative humidity.

\section{Estimation of ventilation rates}

The ventilation rate was calculated using the carbon dioxide balance method. This method is based on the balance between the indoor and outdoor concentrations of carbon dioxide (DIN 18910-1, 2004). Since carbon dioxide is supplied in the barn primarily by the animals, the balance calculation is then based on the principle of the method of constant tracer gas addition. The calculation was based on Eq. 1, as follows:

$$
V=\frac{\dot{m}_{\mathrm{CO}_{2}, T} \cdot N}{C_{\mathrm{CO}_{2}, F_{0}}-C_{\mathrm{CO}_{2}, F_{r}}}
$$

\section{Quantification of gaseous emissions}

Aerial gases $\left(\mathrm{NH}_{3}, \mathrm{CH}_{4}, \mathrm{CO}_{2}\right.$ and $\left.\mathrm{N}_{2} \mathrm{O}\right)$ emissions mass flow rates were calculated using Eq. 2 (Müller et al., 2006):

$$
\dot{m}_{F o-F r}=\left(C_{F o}-C_{F r}\right) \cdot \dot{V}
$$

\section{Sensitivity analysis}

Sensitivity analysis (study of uncertainty in a mathematical model or a numerical system output) can be apportioned to different sources of uncertainty in its inputs.

\section{Table (1). Instruments used to perform the measurements.}

\begin{tabular}{lcc}
\hline Parameter & Measurement Technology & Number of Instruments \\
\hline $\begin{array}{l}\text { Temperature } \\
\text { and relative humidity }\end{array}$ & $\begin{array}{c}\text { Temperature-Humidity sensor } \\
\text { (course measurements) } \\
\text { Gus concentration }\end{array}$ & 5 \\
Wind velocity & $\begin{array}{c}\text { (course measurements) } \\
\text { Weather station } \\
\text { (course measurements) }\end{array}$ & 1 \\
\hline
\end{tabular}




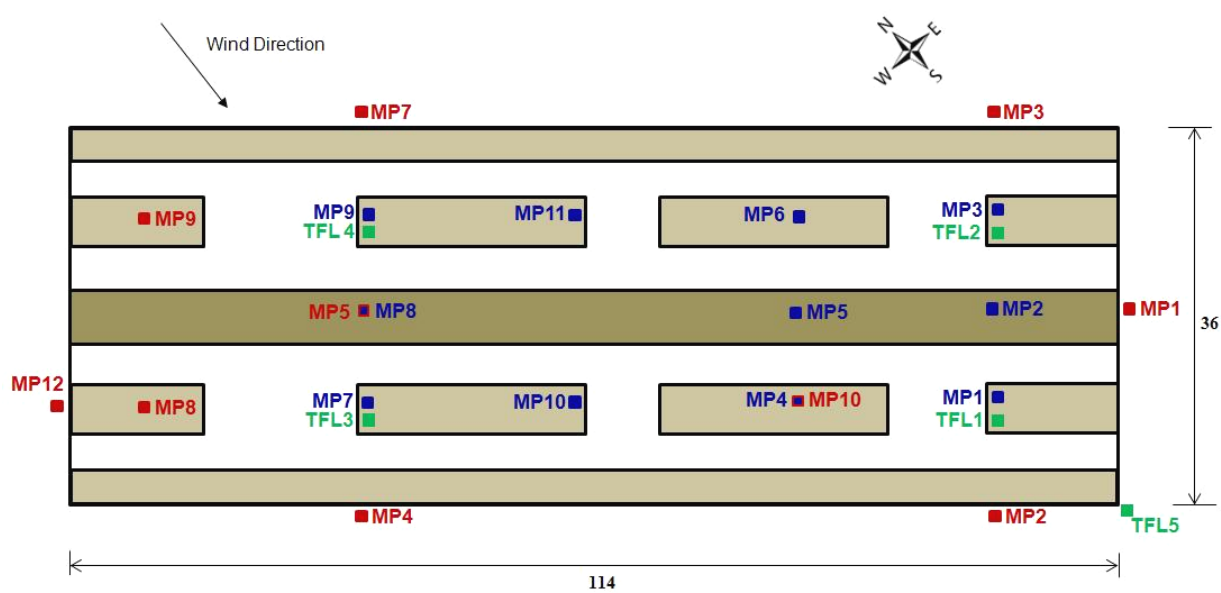

Fig. (1). Investigated barn plan view, (Red MP: first multi-gas monitor; blue MP: second multi-gas monitor; TFL: temperature-humidity sensor). The light-colored areas are the freestalls, and the dark-colored area is the feeding table in the middle of the barn.

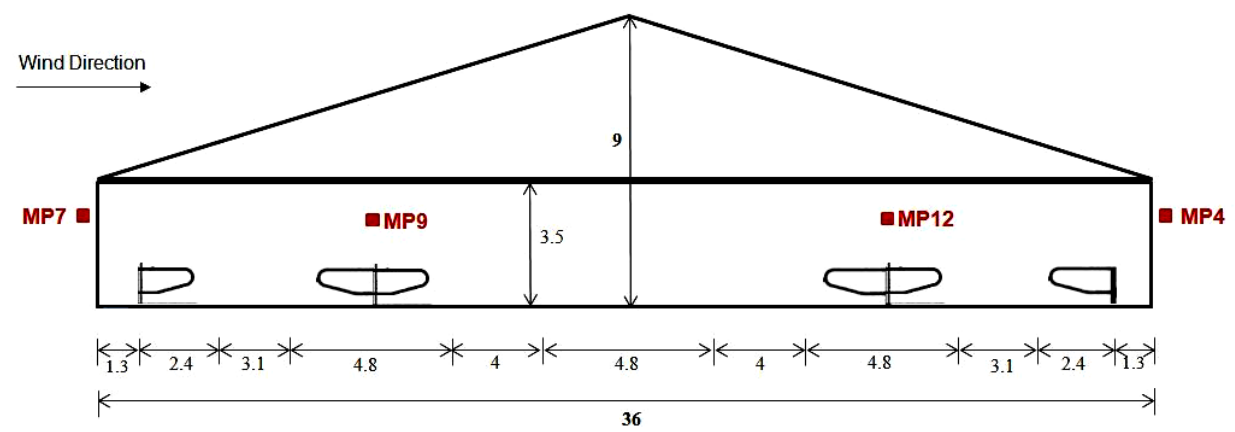

Fig. (2).Side view of the investigated dairy barn (MP: gas sampling point; TFL: temperature-humidity sensor).

In order to estimate the influence of individual assumptions on the overall result of calculated ventilation rates and gaseous emission mass flow rates of ammonia, methane, carbon dioxide and nitrous oxide, so, sensitivity analysis method was applied in the present work. The sensitivity $S$ is the ratio of the relative change of the target size and the relative change of a parameter or an input variable (Flassak et al., 1996). The target of interest $\bar{a}$ is a function of the parameters $b, c$ and $d$ (Fig. 3), where the sensitivity $S$ of $\bar{a}$ can be determined using Eq. 3:

$$
S_{\bar{a} \rightarrow b}=\frac{\frac{\triangle \bar{a}}{\bar{a}}}{\frac{\triangle b}{b}}
$$




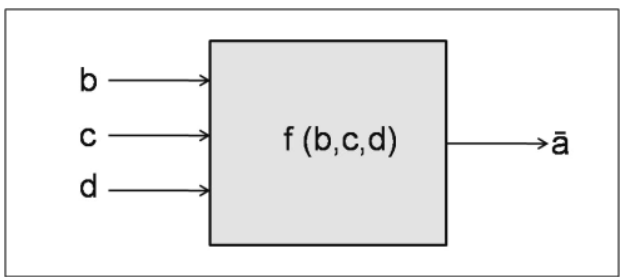

Fig.(3). Schematic representation of an example process: the target of interest $\bar{a}$ as a function of the three input variables $b, c$ and $d$.

Flassak et al. (1996) stated that if, for example, the sensitivity is 0.8 then the variation of the input size by $10 \%$ causes a change of the target by $8 \%$. Direct comparison of the various parameters in terms of their accuracy requirements is considered as the main advantage of this method. Sensitivities of 1 or -1 value show that the relative changes in the input variable induce an almost equally large relative change of the target. A decrease in the target with an increase in an input parameter will reflected in negative sensitivities and vice versa. Sensitivities, which are greater in magnitude than one, indicate a particularly strong influence of the considered parameter to the target size, which imply that this parameter must be specially designed exactly.

\section{Statistical analysis}

Correlation analysis refers to any of a broad class of statistical relationships involving dependence, (any statistical relationship between two random variables or two sets of data) and regression analysis (a statistical method that estimates the relationships among variables). This statistical method models and analyzes several variables, and focuses on the relationship between a dependent variable and one or more independent variables. Furthermore, $t$-test can be used to determine if two sets of data are significantly different from each other (Field, 2009).

Based on the above mentioned concepts, correlation and regression analysis were implemented to derive the predictive relationships and the regression functions that estimate the relationships between $\mathrm{NH}_{3}$ and $\mathrm{CH}_{4}$ concentrations on the one hand and between $\mathrm{CH}_{4}$ and $\mathrm{CO}_{2}$ on the other hand. The coefficient of determination $\left(\mathrm{R}^{2}\right)$ was estimated for each of the derived functions. A multiple $t$-test was conducted for all gases to find out whether the interior concentrations at the different measuring points 
differ significantly from each other. The means and the standard deviations were calculated, then coefficients of variations, (the ratio of standard deviation to the mean) can be calculated. The coefficient of variation shows clearly the amount of variation expressed. The statistical analysis was carried out using SAS v.9.2 (SAS Institute, Inc., Cary, N.C., USA). The 3D plots were drawn using MATLAB (MathWorks, Inc. Natick, Massachusetts, USA).

\section{RESULTS AND DISCUSSION}

\section{Indoor and outdoor conditions}

Mean outdoor and indoor temperatures were of $9.1^{\circ} \mathrm{C}$ and $10.6^{\circ} \mathrm{C}$, respectively, during the experiments. Fig. 4 shows the results of the course measurements of wind speed and wind direction during whole experimental measurements. Both wind direction and speed fluctuated, with average wind direction of $215^{\circ}$ and average wind speed of $2.9 \mathrm{~m} \mathrm{~s}^{-1}$ throughout the experiments.

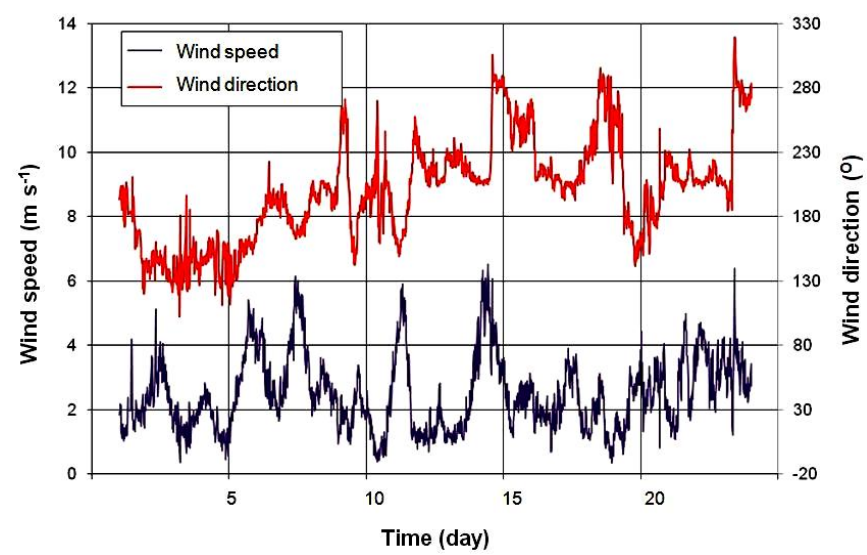

Fig.(4). Course measurements of wind speed and wind direction during the whole measurement campaign.

\section{Indoor concentrations of gases}

The results of correlation analysis of ammonia and methane gases are shown in Fig. 5. The axes were randomly selected, since there is no essential relationship between these two variables. The coefficient of determination of the regression function underlines an average correlation between ammonia and methane concentrations. 


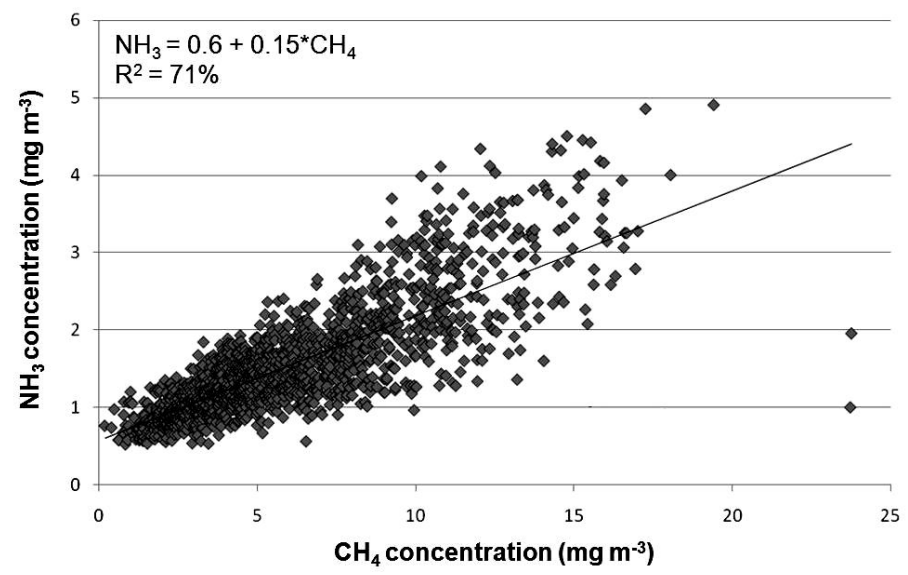

Fig.(5). Estimated relationship between $\mathrm{NH}_{3}$ and $\mathrm{CH}_{4}$ concentrations (Regression function, $R^{2}$ is the coefficient of determination).

The following linear relationship was derived between ammonia and methane concentrations:

$$
\mathrm{NH}_{3}=0.6+0.15 \mathrm{CH}_{4},\left(\mathrm{mg}^{-3} \mathrm{~m}^{-3}\right) ; \quad \mathrm{R}^{2}=71 \%
$$

The correlation between ammonia and carbon dioxide concentrations showed a weaker relationship than between the ammonia and methane concentrations, where the regressions function was:

$$
\mathrm{NH}_{3}=-3.2+0.01 \mathrm{CO}_{2},\left(\mathrm{mg} . \mathrm{m}^{-3}\right) ; \mathrm{R}^{2}=\mathbf{5 6 \%}
$$

The previously established theory for methane and carbon dioxide concentrations using a regression analysis was checked. The corresponding linear regression is shown in Figure 6.

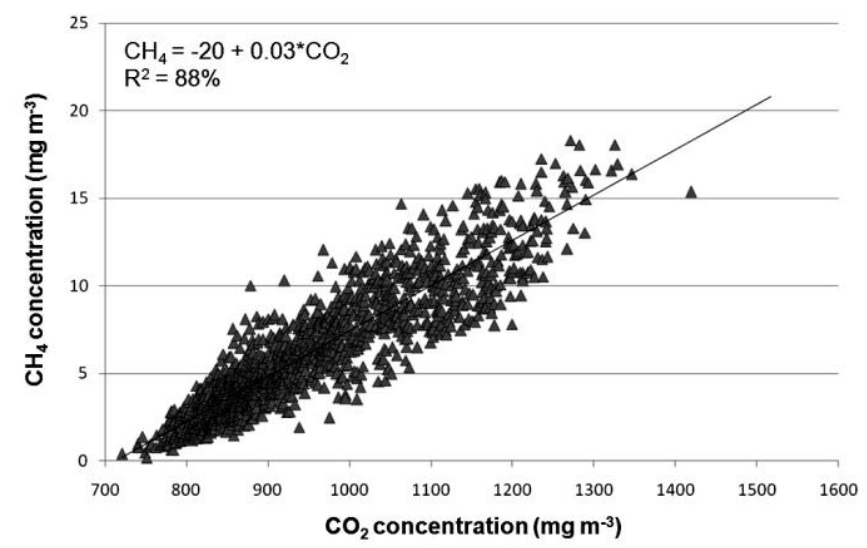

Fig. (6). Regression function that estimates the relationship between $\mathrm{CH}_{4}$ and $\mathrm{CO}_{2}$ concentrations, where $R^{2}$ is the coefficient of determination. 
The axes were randomly selected, because there is no causal relationship between these two gases. The coefficient of determination $\left(\mathrm{R}^{2}\right)$ of the regression functions of $88 \%$ indicates a high correlation between the concentrations of both gases in question. The linear relationship between the concentrations of methane and carbon dioxide was as follows:

$$
\mathrm{CH}_{4}=-20+0.03 \mathrm{CO}_{2},\left(\mathrm{mg} \mathrm{m}^{-3}\right) ; \quad \mathbf{R}^{2}=\mathbf{8 8 \%}
$$

Afterwards, the spatial distribution of the mean gas concentrations is examined overall points inside and outside the investigated barn. The spatial distributions of the average interior concentrations of ammonia, methane, carbon dioxide and nitrous oxide gases are shown in Figs. 7 through 10. The following views toward the barn were understood when one of the northern corners of the barn (Fig. 1) is facing the north. The direction of the prevailing wind throughout the experimental period is illustrated, using the arrow, and was $215^{\circ}$ approximately.

Figs. 7 through 10 show that indoor concentrations of $\mathrm{NH}_{3}, \mathrm{CH}_{4}$ and $\mathrm{CO}_{2}$ gases were significantly higher $(\mathrm{p}<0.05)$ than the outdoor concentrations. This is particularly obvious for $\mathrm{CH}_{4}$ (Fig. 8). Additionally, an important tendency for these three gases was observed where the indoor gaseous concentrations are affected by the prevailing wind direction (from north). The average $\mathrm{CH}_{4}$ concentration at the southern side of the barn was $8.1 \mathrm{mg} \mathrm{m}^{-3}$ which is almost twice as high as the average methane concentration at the northern side of the barn which was $4.3 \mathrm{mg} \mathrm{m}^{-}$ ${ }^{3}$. Furthermore, Figs. 7 to 9 show that the maximum concentrations of the gases $\mathrm{NH}_{3}, \mathrm{CH}_{4}$ and $\mathrm{CO}_{2}$, which were measured at the measuring point 8 (Fig. 1). The values were 1.6 to 2.2 times the measured values by the other points. A multiple $t$-test was conducted for all gases to find out whether indoor concentrations at the different measuring points differ significantly from each other. The analysis showed that the indoor concentrations of the different gases in the vicinity of the barn were significantly different from each other $(p<0.05)$, which means that the spatial distribution of indoor gaseous concentrations is not homogeneous. Regarding the gases $\mathrm{NH}_{3}$ and $\mathrm{CH}_{4}$, it was found that the gas concentrations at the measuring point 8 differ significantly $(\mathrm{p}<0.001)$ from the gas concentrations of the other internal measurement points. On the other hand, 
the concentrations of carbon dioxide at the measurement points 8 and 11 did not differ significantly from each other.
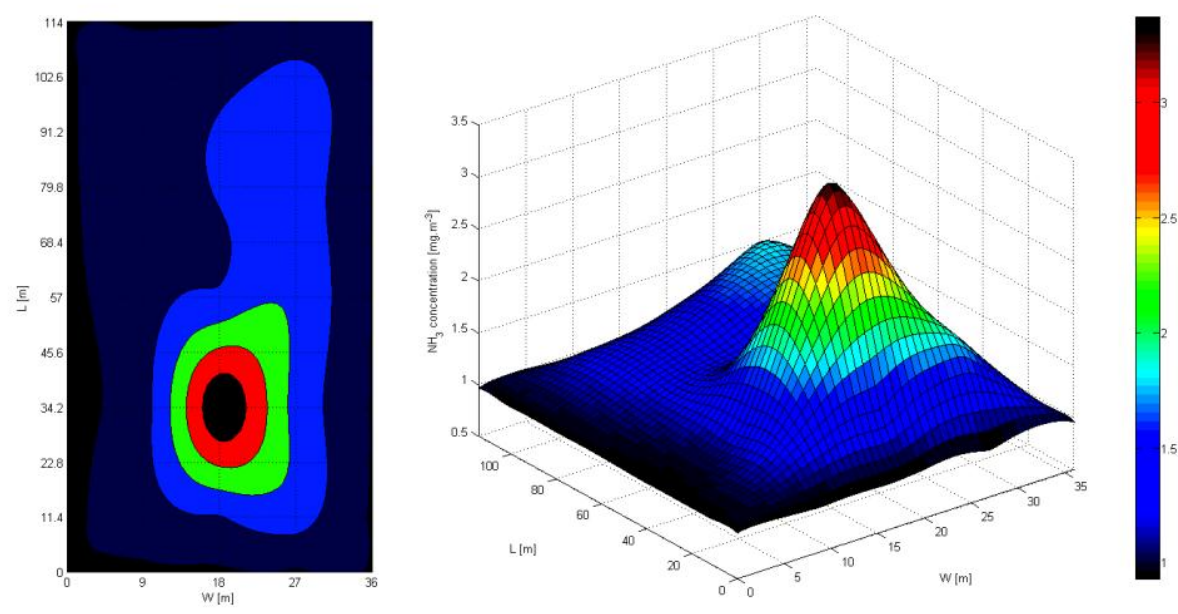

Fig.(7). Spatial distribution of mean $\mathrm{NH}_{3}$ concentrations for all MPs during the measurement campaign.
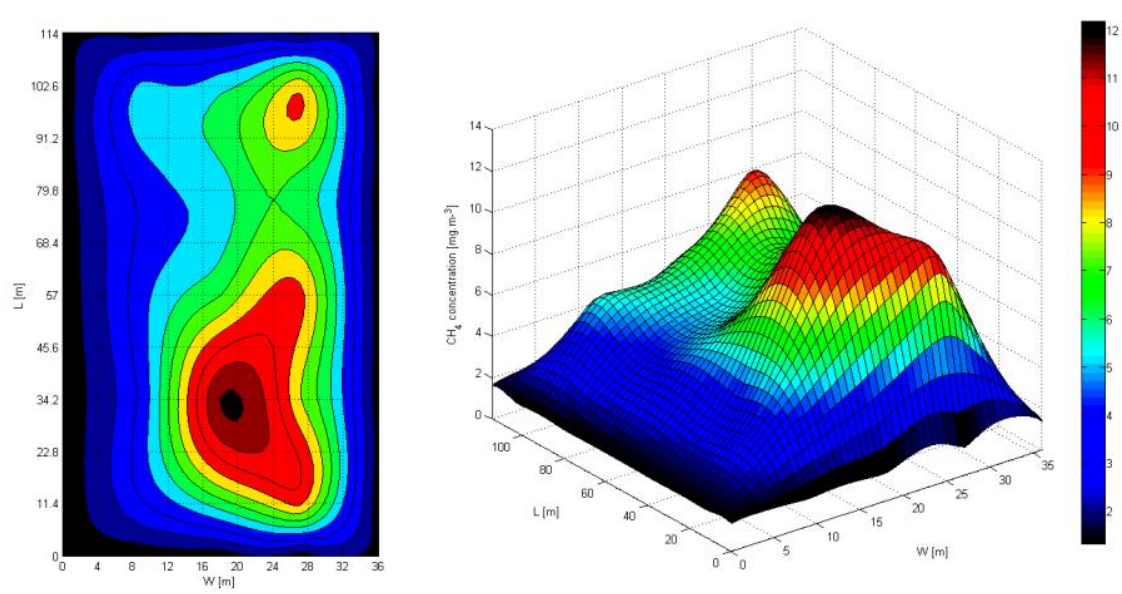

Fig. (8). Spatial distribution of mean $\mathrm{CH}_{4}$ concentrations for all MPs during the measurement campaign.

The concentrations of these two measurement points, however, differ significantly $(\mathrm{p}<0.001)$ from the concentrations of all other measurement points. In addition to the indoor concentrations of the gases $\mathrm{NH}_{3}$, $\mathrm{CH}_{4}$ and $\mathrm{CO}_{2}$, it was found that the concentrations at the measurement points located at the northern long side of the barn were not significantly 
different from each other. Which is means that there is a homogeneous distribution of the concentrations of these gases at the northern side of the barn. Otherwise, no homogeneous distribution of the concentrations of these gases was found at the southern side of the barn. In general, the concentrations of these three gases sampled at the northern side of the barn differ significantly $(p<0.05)$ from the concentrations of these gases sampled at the southern side of the barns.
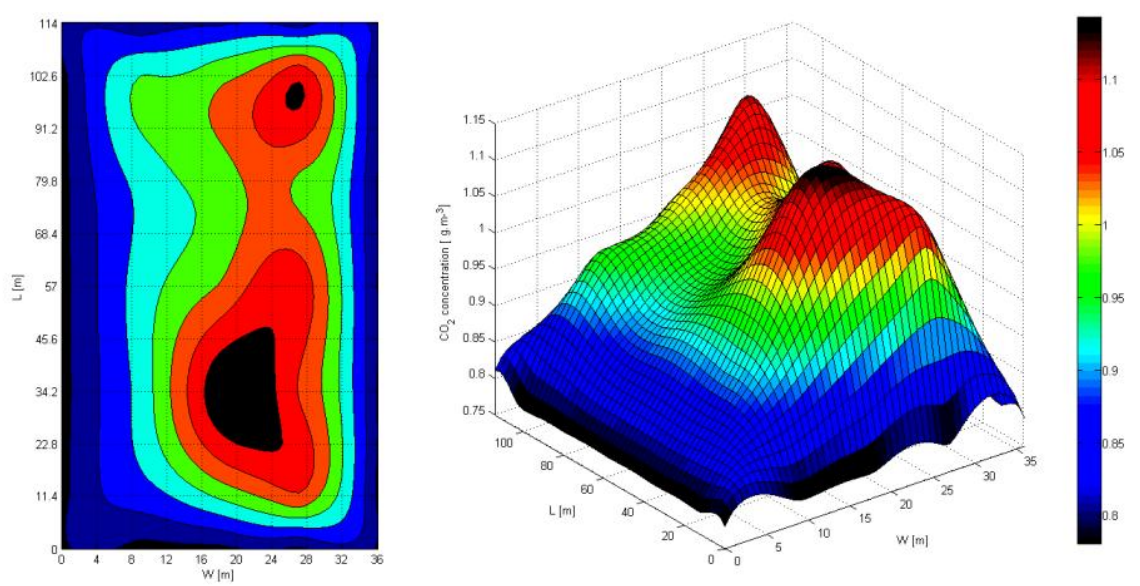

Fig.(9). Spatial distribution of mean $\mathrm{CO}_{2}$ concentrations for all MPs during the measurement campaign.
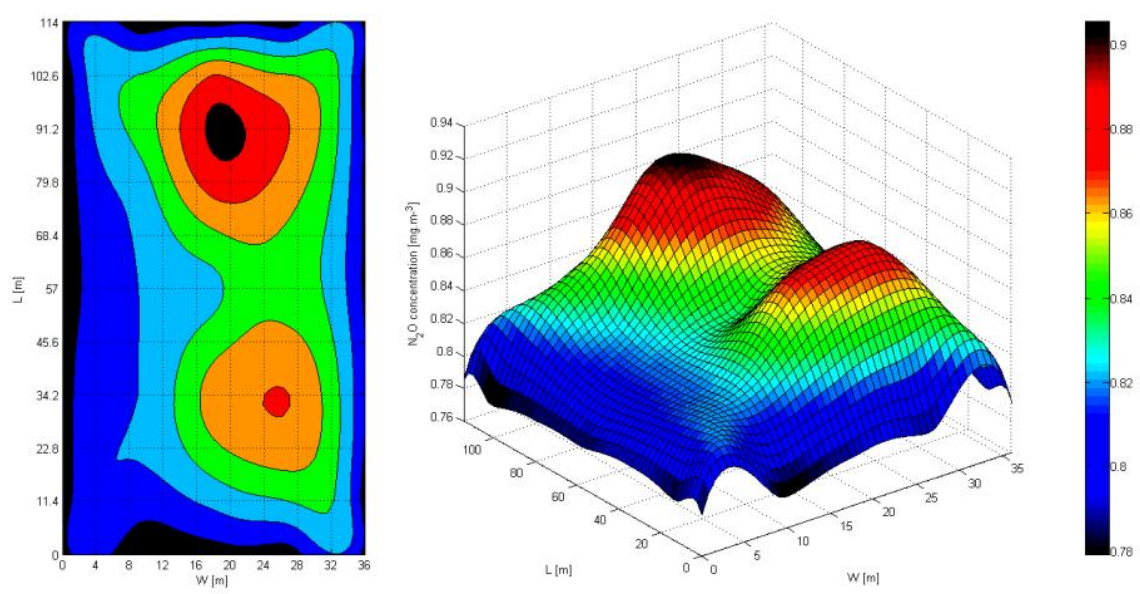

Fig.(10). Spatial distribution of mean $\mathrm{N}_{2} \mathrm{O}$ concentrations for all MPs during the measurement campaign. 


\section{Ventilation rates}

The ventilation rates were estimated using the carbon dioxide balance method. Table 2 shows the means of the air exchange rate and the ventilation rate with the standard deviations. The high standard deviations display the high variability of the ventilation rates.

\section{Emission rates}

Gaseous average emission mass flow rates of ammonia, methane, nitrous oxide and carbon dioxide are presented in Table 3 . The mean emission mass flow rates of ammonia and nitrous oxide have coefficient of variation of $65 \%$ and $78 \%$, respectively, which elucidates very high fluctuations. The coefficient of variation of carbon dioxide was very low and was about $5 \%$.

Table (2). Means and standard deviations of air exchange rate and ventilation rate.

\begin{tabular}{lccc}
\hline & $\begin{array}{c}\text { Air exchange } \\
\text { rate }\left(\mathrm{h}^{-1}\right)\end{array}$ & $\begin{array}{c}\text { Ventilation } \\
\text { rate }\left(\mathrm{m}^{3} \mathrm{~s}^{-1}\right)\end{array}$ & $\begin{array}{c}\text { Ventilation rate per } \\
\text { cow }\left(\mathrm{m}^{3} \mathrm{~h}^{-1} \text { cow }^{-1}\right)\end{array}$ \\
\hline Mean & 50.1 & 348.4 & 3053 \\
\hline $\begin{array}{l}\text { Standard } \\
\text { deviation }\end{array}$ & 24.3 & 169.3 & 1482 \\
\hline
\end{tabular}

Table (3). Mean emission mass flow rates with standard deviations and the specific emission factors of $\mathrm{NH}_{3}, \mathrm{CH}_{4}, \mathrm{CO}_{2}$ and $\mathrm{N}_{2} \mathrm{O}$ during the measurement campaign.

\begin{tabular}{lccc}
\hline Gas & $\begin{array}{c}\text { Emission mass flow } \\
\text { rates }\left(\mathrm{g} \mathrm{h}^{-1}\right) \pm \text { stand- } \\
\text { ard deviation }\end{array}$ & $\begin{array}{c}\text { Emission mass flow } \\
\text { rates per animal unit } \\
\left(\mathrm{g} \mathrm{h}^{-1} \mathrm{AU}^{-1}\right)^{*}\end{array}$ & $\begin{array}{c}\text { Emission mass } \\
\text { flow rates per cow } \\
\left(\mathrm{g} \mathrm{h}^{-1} \text { cow }^{-1}\right)\end{array}$ \\
\hline $\mathrm{NH}_{3}$ & $925.1 \pm 549.3$ & 1.81 & 20.10 \\
$\mathrm{CH}_{4}$ & $5281 \pm 1825$ & 10.20 & 113.80 \\
$\mathrm{CO}_{2}$ & $181980 \pm 5309$ & 351.10 & 3925.00 \\
$\mathrm{~N}_{2} \mathrm{O}$ & $47.8 \pm 33.2$ & 0.10 & 1.10 \\
\hline
\end{tabular}

*AU is animal unit which is equal $500 \mathrm{~kg}$

Fig. 11 shows the $\mathrm{NH}_{3}$ and $\mathrm{CH}_{4}$ emission mass flow rates in the course of a daily average over the 21 days of the measurement campaign. After milking the cows at 06:00, 14:30 and 21:30 $\mathrm{HR}$, the emissions of $\mathrm{NH}_{3}$ and $\mathrm{CH}_{4}$ increase noticeably. The effect of feeding on the level of the $\mathrm{CH}_{4}$ emissions can be recovered from the figure, where the cows were fed twice a day. The first feeding took place in the morning after first milking period, where, an increase in $\mathrm{CH}_{4}$ emissions was observed. In the 
afternoon, between 16:30 and 18:30 HR, the cows were supplied with fresh forages. The second feeding time is not fixed. Due to the fact that the emissions were averaged over 21 days, the second feed-related peak emission is not clearly observable as of the morning. Fig. 12 shows the course of animal activity based on the average of daily results through the measurements campaign. The animal activity is important for interpreting the diurnal variation of interior gaseous concentrations.

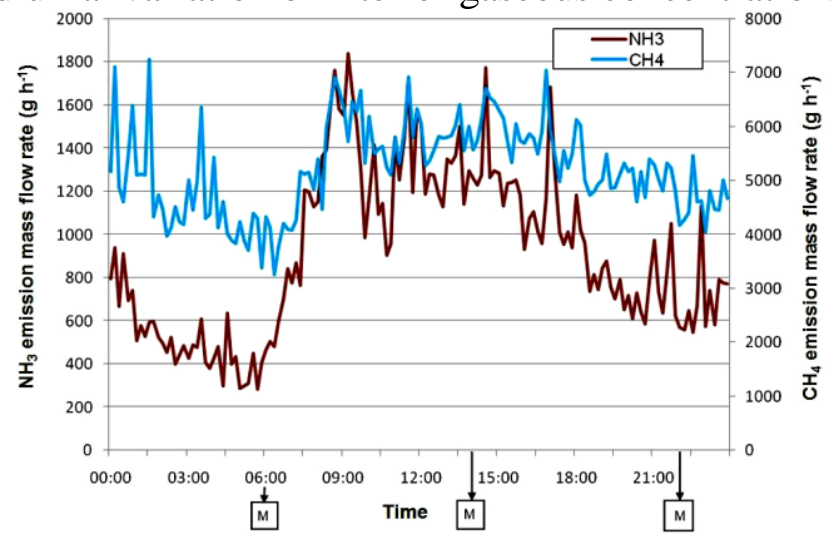

Fig. (11). $\mathrm{NH}_{3}$ and $\mathrm{CH}_{4}$ emission mass flow rates in the course of a day averaged over the 21 days of the measurement campaign (M referrers to the milking time).

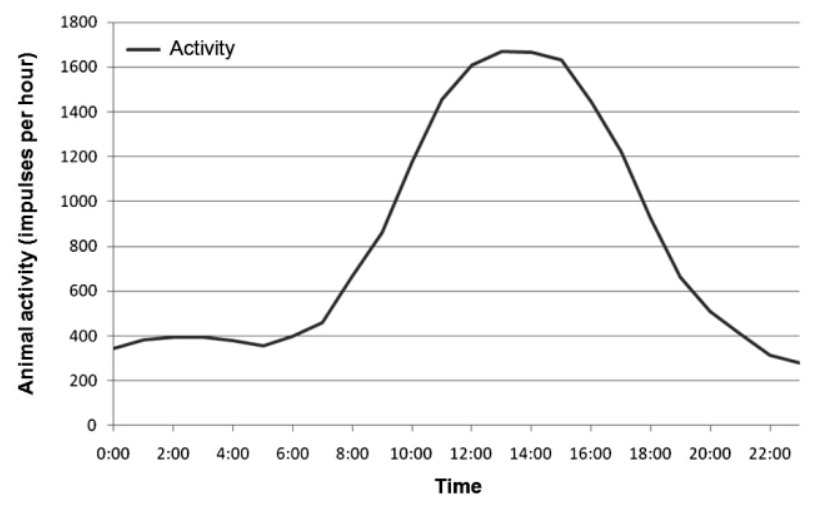

Fig.(12). Cows' activity in the course of a day averaged over the 21 days of the measurement campaign.

\section{Sensitivity analysis}

The variations of the individual input parameters have very different effects on the overall performance and calculation result of the ventilation rate (Table 4). The input variables of $\mathrm{CO}_{2}$ concentration difference between indoor and outdoor air and $\mathrm{CO}_{2}$ produced by the animals have a strong influence on the overall result of the ventilation rate calculation. A 
variation of any of these parameters by $10 \%$ leads to a change of the target value of ventilation rate by about $7-8 \%$. On the other hand, the negative sensitivities which are based on a reduction in $\mathrm{CO}_{2}$ concentration difference lead to an increase in ventilation rate and vice versa. It was noticed that the input variable of the indoor temperature has little influence on the ventilation rate. An increase or decrease of this value by $10 \%$ causes a decrease or increase in the ventilation rate by $0.7-1.5 \%$. The variation of parameters such as body weight and milk yield by $10 \%$ and $3 \%$ direct to a variation of the ventilation rate by $3 \%$ and $0.1 \%$, respectively. The influence of these parameters on the result of the ventilation rate calculation can also be considered low. The pregnancy has a very small effect on the ventilation rate.

Table (4). Sensitivity $S$ and the relative change of the target ventilation rate in terms of the influencing factors.

\begin{tabular}{lccc}
\hline Input parameter & $\begin{array}{c}\text { Parameter } \\
\text { change }\end{array}$ & Sensitivity $S$ & $\begin{array}{c}\text { Change of the } \\
\text { target size }\end{array}$ \\
\hline $\mathrm{CO}_{2}$ concentration & $+10 \%$ & -0.71 & $-7.10 \%$ \\
difference between & $-10 \%$ & -0.82 & $+8.20 \%$ \\
indoor and outdoor & $+1 \%$ & -0.61 & $-0.61 \%$ \\
air $\left(\mathrm{g} \mathrm{m}^{-3}\right)$ & $-1 \%$ & -0.65 & $+0.65 \%$ \\
$\left(C_{\mathrm{CO}}, \mathrm{Fo}_{\mathrm{o}}-\mathrm{C}_{\mathrm{CO}}, \mathrm{Fr}\right)$ & $+10 \%$ & 0.75 & $+7.50 \%$ \\
\hline & $-10 \%$ & 0.79 & $-7.90 \%$ \\
$\mathrm{CO}_{2}$ production per $^{-1} \mathrm{cow}\left(\mathrm{g} \mathrm{h}^{-1} \mathrm{cow}^{-1}\right)$ & $+1 \%$ & 0.65 & $+0.65 \%$ \\
& $-1 \%$ & 0.62 & $-0.62 \%$ \\
\hline Indoor temperature & $+10 \%$ & -0.07 & $-0.70 \%$ \\
$\mathrm{Ti}\left({ }^{\circ} \mathrm{C}\right)$ & $-10 \%$ & -0.15 & $+1.50 \%$ \\
\hline Body weight $(\mathrm{kg})$ & $+10 \%$ & 0.28 & $+2.80 \%$ \\
\hline Pregnancy $(\mathrm{day})$ & $-10 \%$ & 0.30 & $-3.00 \%$ \\
\hline \multirow{2}{*}{ Milk yield $(\mathrm{kg})$} & $+30 d$ & $<0.1$ & $<0.1 \%$ \\
\hline
\end{tabular}

The variation of this parameter by 30 days leads to a change in the ventilation rate by less than $0.1 \%$. The variation of the input parameter gas concentration difference between indoor and outdoor air and its effect on the result of the emission calculation was investigated. This investigation considered $\mathrm{NH}_{3}$ as an example. Since the emission mass flow rates of a gas can be calculated using Equation 2, the investigation results are trans- 
ferable to the gases $\mathrm{CH}_{4}, \mathrm{CO}_{2}$ and $\mathrm{N}_{2} \mathrm{O}$ which were calculated using the same equation.

Table 5 shows the variations of the input variables of $\mathrm{NH}_{3}$ concentration difference and ventilation rate which bring to mind exactly the same changes in the target $\mathrm{NH}_{3}$ emission mass flow rates. Thus, these input variables have a very strong influence on the amount of the calculated gas emissions. Using the law of propagation of error, i.e. propagation of uncertainty (Blobel and Lohrmann, 1998), the total error of ventilation rate calculation was determined and found to be $10 \%$ approximately.

Table (5). Sensitivity $S$ and the relative change of the target ammonia emission mass flow rate in terms of the influencing factors.

\begin{tabular}{lccc}
\hline Input parameter & $\begin{array}{c}\text { Parameter } \\
\text { change }\end{array}$ & Sensitivity $S$ & $\begin{array}{c}\text { Change of the } \\
\text { target size }\end{array}$ \\
\hline $\mathrm{NH}_{3}$ concentration dif- & $+10 \%$ & 1 & $+10 \%$ \\
ference between indoor & $-10 \%$ & 1 & $-10 \%$ \\
and outdoor air $\left(\mathrm{g} \mathrm{m}^{-3}\right)$ & $+1 \%$ & 1 & $+1 \%$ \\
$\left(C_{N H_{3}, F o}-C_{N H_{3}, F r}\right)$ & $-1 \%$ & 1 & $-1 \%$ \\
\hline Ventilation rate $\left(\mathrm{m}^{3} \mathrm{~h}^{-1}\right)$ & $+10 \%$ & 1 & $+10 \%$ \\
\hline
\end{tabular}

The results of this study showed that emissions flux of harmful gases from naturally ventilated livestock buildings is dependent on wind velocity and, therefore, the emission mass flow is highly changeable and difficult to estimate. This conclusion agrees with the investigations conducted by Ngwabie et al. (2009) and Van Buggenhout et al. (2009). Furthermore, the results of this study agree with Von Bobrutzki et al. (2011) who stated that the dispersion of $\mathrm{NH}_{3}$ is strongly influenced by $\mathrm{NH}_{3}-$ mass-flow and mean wind components and directions. Moreover, the results of the study showed that the $\mathrm{CO}_{2}$ produced by the animals has a severe influence on the estimated ventilation rate which agrees with Xin et al. (2009). The results of this study showed that indoor gaseous concentrations are not homogeneous all over the barn. Consequently, the mass transfer laws apply and the gas flows from higher concentration zone to the zone with lower concentration. This statement is in agreement with Okuyama et al. (2009) and Sherman (1989) who stated that multizone techniques recognize that not only does airflow between the investigated building and the outside, but that there are airflows between dif- 
ferent zones, inside buildings and multizone techniques are able to measure these flows. The average indoor $\mathrm{NH}_{3}$ concentration was $1.44 \mathrm{mg} \mathrm{m}^{-3}$ which is 1.7 times the average outdoor $\mathrm{NH}_{3}$ concentration. The average indoor $\mathrm{CH}_{4}$ concentration was $5.7 \mathrm{mg} \mathrm{m}^{-3}$ which is 16 times the average outdoor $\mathrm{CH}_{4}$ concentration. The average indoor concentration of $\mathrm{CO}_{2}$ was $981.6 \mathrm{mg} \mathrm{m}^{-3}$ which exceeds the outdoor concentration by $219.8 \mathrm{mg}$ $\mathrm{m}^{-3}$. The investigations of Ngwabie et al. (2009) in a similar freestall barn (natural ventilation, open longitudinal sides, slurry-based system) showed that the average indoor concentrations of the gases $\mathrm{NH}_{3}, \mathrm{CH}_{4}$ and $\mathrm{CO}_{2}$ were 6.4, 14.8 and 3 times the outdoor concentrations of these gases, respectively; which harmonizes only with the results of $\mathrm{CH}_{4}$ in the present study. On the other hand, $\mathrm{CH}_{4}$ had the highest concentration differences between indoor and outdoor air compared to the other gases. The differences between indoor and outdoor concentrations of $\mathrm{N}_{2} \mathrm{O}$ were not significant. This confirms that there are no sources of $\mathrm{N}_{2} \mathrm{O}$ inside the barn. This is consistent with the statement of Hüther (1999) who stated that the liquid manure systems release little or no $\mathrm{N}_{2} \mathrm{O}$ due to the fact that the liquid manure contains few amounts of nitrate and nitrite, which can be converted to $\mathrm{N}_{2} \mathrm{O}$ by nitrification and denitrification under aerobic conditions where the presence of oxygen is obligatory. The gases $\mathrm{NH}_{3}$, $\mathrm{CH}_{4}$ and $\mathrm{CO}_{2}$ are released inside the barn from different sources. Ammonia is emitted from the excrements of the animals (Hartung, 1995). Methane is emitted from the excrements as well as by eructation of animals (Hartung, 2001). Carbon dioxide is produced mainly by animal respiration with a little amount produced from the animal excrements (Kinsman et al., 1995). The results of the regression analysis showed a weak relationship between $\mathrm{NH}_{3}$ and $\mathrm{CO}_{2}\left(\mathrm{R}^{2}=56 \%\right)$ and an unreliable relationship between $\mathrm{NH}_{3}$ and $\mathrm{CH}_{4}\left(\mathrm{R}^{2}=71 \%\right)$. In contrast, the regression analysis showed a reliable relationship between $\mathrm{CH}_{4}$ and $\mathrm{CO}_{2}\left(\mathrm{R}^{2}=88 \%\right)$. This can be explained by the fact that both $\mathrm{CH}_{4}$ and $\mathrm{CO}_{2}$ have the same main source which is the animals. The spatial distribution of the indoor gaseous concentrations is highly affected by the wind direction, whereas the barn is naturally ventilated. Generally, the spatial distribution of indoor gaseous concentration is not homogeneous. The gaseous concentrations were higher at the leeward side of the barn than the windward side of the barn. Focusing on the windward side, the measurements of gaseous concentrations showed a homogeneous distribution through the windward 
side. This can be explained by the fact that when the wind intrudes into the barn a few air vortices may take place. However, the longer the distance from the air inlets the more and stronger air vortices take place, which result in a non-homogeneous distribution of gaseous concentrations. An example for this occurrence is the results of measuring point 8 (MP8) which measured higher gaseous concentrations than the surrounding points.

In the literature, the $\mathrm{NH}_{3}$ emissions factor from freestalls barns for dairy cows was in the range between $1 \mathrm{~g} \mathrm{~h}^{-1} \mathrm{AU}^{-1}$ and $2.4 \mathrm{~g} \mathrm{~h}^{-1} \mathrm{AU}^{-1}$ (Seipelt, 1999; Schneider et al., 2006; Ngwabie et al., 2009). The emissions factor of $\mathrm{CH}_{4}$ ranged from $8.6 \mathrm{~g} \mathrm{~h}^{-1} \mathrm{AU}^{-1}$ and $23 \mathrm{~g} \mathrm{~h}^{-1} \mathrm{AU}^{-1}$. In the present study, the emissions factors of $\mathrm{NH}_{3}$ and $\mathrm{CH}_{4}$ were $1.8 \mathrm{~g} \mathrm{~h}^{-1} \mathrm{AU}^{-1}$ and 10.2 $\mathrm{g} \mathrm{h}^{-1} \mathrm{AU}^{-1}$, respectively. These results are in the ranges given in the literature. The emissions factor of $\mathrm{N}_{2} \mathrm{O}$, in the present study, was very low where the determined value was about $0.1 \mathrm{~g} \mathrm{~h}^{-1} \mathrm{AU}^{-1}$ which disagrees with that of Schneider et al. (2006) who found a value of 0.70 and $0.74 \mathrm{~g}$ $\mathrm{N}_{2} \mathrm{O} \mathrm{h}^{-1} \mathrm{AU}^{-1}$ in two different barns. This disagreement regarding the $\mathrm{N}_{2} \mathrm{O}$ emissions factor can be attributed to the fact that $\mathrm{N}_{2} \mathrm{O}$ release inside the barn is dependent on several factors such the temperature and the aerobic conditions required by the nitrification and denitrification processes which are responsible of $\mathrm{N}_{2} \mathrm{O}$ release. Another cause is the feed which is a source of $\mathrm{N}_{2} \mathrm{O}$ release, where the feed rations differ substantially between both the investigated barn in the present study and the barns in investigated by Schneider et al. (2006). The mean diurnal variations and trends of $\mathrm{NH}_{3}$ and $\mathrm{CH}_{4}$ emissions (Fig. 11) are in full agreement with the activities of the dairy cows (Fig. 12). In the early morning hours, the lowest emission levels were found due to lowest activity of the animals. The activities of the dairy cows were increased by the milking and feeding processes. The $\mathrm{CH}_{4}$ release and emissions are increased by the feed intake and the digestion processes, during the feeding period, which release the accumulated $\mathrm{CH}_{4}$ in the rumen through eructation. Kinsman et al. (1995) stated that the diurnal variations of $\mathrm{CH}_{4}$ emissions are primarily influenced by the feeding, where they found variation trends similar to those found by the present study. On the other hand, through the feed intake process, the feed enters the rumen which causes a pressure that leads to excrete the rest of the previously digested feed ration, the excreted feces and manure increase the release of $\mathrm{NH}_{3}$ which 
explains the trend shown in Figure 11. This can be further elucidated by the statements of Hartung (1995) who mentioned that the increased excretion of urine and faeces after the milking and at the beginning of feeding led to an increase in $\mathrm{NH}_{3}$ emissions. The excrements come to the contact with the urease present in urine with the nitrogen compounds of the manure; thereby $\mathrm{NH}_{3}$ is formed and released inside the barn which increases the indoor $\mathrm{NH}_{3}$ concentrations and as a result the $\mathrm{NH}_{3}$ emissions mass flow rates increase. In the present study, the different sensors were symmetrically distributed inside the building to cover the whole area of the barn, where this procedure is usually implemented by similar studies in the literature (Ngwabie et al., 2009; Samer et al. 2011a,b). However, in order to get better results in the future investigations, it is recommended to implement the method of finite elements analysis to determine accurately the best locations of the different sensors inside the investigated livestock building. This requires a separate intensive investigation that focuses on the implementation of the methodology of the finite elements analysis.

\section{CONCLUSIONS}

Based on the results of this study, it can be concluded that:

1. The spatial distribution of interior concentrations of ammonia, methane and carbon dioxide gases is not homogeneous.

2. Indoor concentrations of these gases were significantly higher than the outdoor concentrations.

3. Indoor concentrations of ammonia, methane and carbon dioxide sampled at the leeward side of the barn were significantly higher than that at the windward side of the barn.

4. The spatial distribution of the indoor gaseous concentrations is affected by the prevailing wind direction, whereas the barn is naturally ventilated.

5. The trends of the diurnal variations of indoor gaseous concentrations and consequently the emissions mass flow rates are dependent on the animal activity, milking and feeding processes. The emissions increase noticeably after milking, during the feeding period and with animal activity.

6. $\mathrm{CO}_{2}$ concentration difference between indoor and outdoor air and the $\mathrm{CO}_{2}$ produced by the animals, strongly, affect ventilation rate calculations when the $\mathrm{CO}_{2}$-balance is implemented. 
7. Gas concentration difference between indoor and outdoor air and the ventilation rate have strong influence on the emission mass flow rate of this gas.

\section{LIST OF SYMBOLS}

\begin{tabular}{|l|l|}
\hline$\dot{V}$ & Volumetric airflow rate, $m^{3} h^{-1}$ \\
\hline$\dot{m}_{\mathrm{CO}_{2}, T}$ & $\mathrm{CO}_{2}$ mass production rate per animal, $g h^{-1}$ \\
\hline$N$ & Number of animals \\
\hline$C_{\mathrm{CO}_{2}, F_{0}}$ & Indoor $\mathrm{CO}_{2}$ concentration, $g m^{-3}$ \\
\hline$C_{\mathrm{CO}_{3}, F_{\mathrm{r}}}$ & Outdoor $\mathrm{CO}_{2}$ concentration, $g m^{-3}$ \\
\hline$\dot{m}_{F_{0}-F_{Y}}$ & Emissions mass flow rate from the barn, $g h^{-1}$ \\
\hline$C_{F_{0}}$ & Indoor gas concentration, $g m^{-3}$ \\
\hline$C_{F_{Y}}$ & Outdoor gas concentration, $g m^{-3}$ \\
\hline$S_{\bar{a} \rightarrow b}$ & Sensitivity of $\bar{a}$ with respect to the input parameter $b$ \\
\hline$\triangle \bar{a}$ & $\begin{array}{l}\text { Variation of } \bar{a} \text { as result of the variation of the input pa- } \\
\text { rameter } b\end{array}$ \\
\hline $\bar{a}$ & Mean value of the target variable \\
\hline$\triangle b$ & Variation or change in the input parameter $b$ \\
\hline$b$ & Input parameter \\
\hline
\end{tabular}

\section{REFERENCES}

Abdelbary, K. M.; M. H. Hatem; N. E. Gohar and A. E. Ghaly. 2004. Engineering and environmental studies on ammonia emitted from poultry houses. Conf. of Environ. \& Sustainable Dev., 44th Ann. Sci. Week Activities, The Supreme Council of Sci., Al Baath Univ., Syria.

Abdel-Rahman, G. M., K.M. Abdelbary and I. H. Al-Homidan. 2010. Study of air pollutants, Part (1): Ammonia and dust emissions patterns inside poultry houses. Misr Society of Agricultural Engineering, 27(4): 1381-1399.

Abdel-Rahman, G. M., K.M. Abdelbary and I. H. Al-Homidan. 2011. Study of air pollutants, Part (2): Effect of ventilation rates on ammonia and dust emissions inside poultry houses. Misr Society of Agricultural Engineering, 28(1): 230-249.

Adviento-Borbe, M., E.F. Wheeler, N.E. Brown, P.A. Topper, R.E. Graves, V.A. Ishler and G.A. Varga. 2010. Ammonia and greenhouse gas flux from manure in freestall barn with dairy cows on precision fed rations. Transactions of the ASABE, 53(4):1251-1266. 
Berg, W., 1999. Technology assessment-livestock management. Anim. Res. Dev., 50: 98-109.

Bjorneberg, D.L., A.B. Leytem, D.T. Westermann, P.R. Griffiths, L. Shao and M.J. Pollard. 2009. Measurements of atmospheric ammonia, methane, and nitrous oxide at a concentrated dairy production facility in southern Idaho using open-path FTIR spectrometry. Transactions of the ASABE, 52(5):1749-1756.

Blanes-Vidal, V., P.A. Topper and E.F. Wheeler. 2007. Validation of ammonia emissions from dairy cow manure estimated with a non-steady-state, recirculation flux chamber with whole building emissions. Transactions of the ASABE, 50(2):633-640.

Blobel, V. and E. Lohrmann. 1998. Statistische und numerische Methoden der Datenanalyse (In German, Statistical and numerical methods of data analysis). Teubner Books, Stuttgart, Germany.

CIGR. 1994. Aerial environment in animal housing: Concentrations in and emissions from farm buildings. Working Group Report number 94.1: Climatization and environmental control in animal housing. International Commission of Agricultural Engineering (CIGR).

DIN 18 910-1. 2004. Wärmeschutz geschlossener Ställe: Wärmedämmung und Lüftung (In German, Thermal insulation for confined barns: Thermal insulation and ventilation). Part 1: Planning and basic calculations for confined barns with forced ventilation. Beuth Publisher, Germany.

FAO. 2006. Livestock's role in climate change and air pollution. Available at: ftp://ftp.fao.org/docrep/fao/010/a0701e/A0701E03.pdf. Accessed December 2010.

Field, A. 2009. Discovering Statistics Using SPSS. $3^{\text {rd }}$ Edition. ISBN 978-1-84787-907-3, SAGE Publications, California, USA.

Flassak, T., W. Bächlin, R. Bösinger, G. Blazek and A. Lohmeyer. 1996. Einfluss der Eingangsparameter auf berechnete Immissionswerte für Kfz-Abgase: Sensitivitätsanalyse (In German, Influence of the input parameters on calculating emission values: Sensitivity analysis). European research project for measures on air pollution (FZKA-PEF 150), Karlsruhe Research Center, Germany. 
Hartung, E. 1995. Entwicklung einer Messmethode und Grundlagenuntersuchung zur Ammoniakfreisetzung aus Flüssigmist (In German, Development of a measurment method and basic research for investigating ammonia release from liquid manure). PhD Dissertation, University of Hohenheim, Germany.

Hartung, E. 2001. Methan- und Lachgas-Emissionen der Rinder-, Schweine- und Geflügelhaltung. (In German, $\mathrm{CH}_{4}$ and $\mathrm{N}_{2} \mathrm{O}$ emissions from cattle, pig and poultry housing). In: Emissionen der Tierhaltung: Grundlagen, Wirkungen, Minderungsmaßnahmen (In: Emissions from animal housing: Basics, effects, and abatement techniques). KTBL-Script 406 (KTBL ed.), Darmstadt, Germany.

Hüther, L. 1999. Entwicklung analytischer Methoden und Untersuchungen von Einflussfaktoren auf Ammoniak-, Methanund Distickstoffmonoxidemissionen aus Flüssig- und Festmist (In German, Development of analytical methods for investigating the influencing factors on $\mathrm{NH}_{3}, \mathrm{CH}_{4}$ and $\mathrm{N}_{2} \mathrm{O}$ emissions from manure). PhD Dissertation, Technical University of Brauschweig, Germany.

IPCC. 2007. Climate Change 2007: Mitigation. Contribution of Working Group III to the $4^{\text {th }}$ Assessment Report of the Intergovernmental Panel on Climate Change. B. Metz, O. R. Davidson, P. R. Bosch, R. Dave, and L. A. Meyer, eds. Cambridge University Press, Cambridge, United Kingdom and New York, NY, USA.

Kinsman, R., F.D. Sauer, H.A. Sauer, M.S. Wolynetz and H.A. Jackson. 1995. Methane and carbon dioxide emissions from dairy cows in full lactation monitored over a six-month period. Journal of Dairy Cows, 78: 2760 - 2766.

Morsing, S., J.S. Strom, G. Zhang and P. Kai. 2008. Scale model experiments to determine the effects of internal airflow and floor design on gaseous emissions from animal houses. Biosystems Engineering, 99:99-104.

Müller, H.-J., R. Brunsch and W. Berg. 2006. Ammoniakemissionsmassenströme in und um Tierhaltungsanlagen (In German, Ammonia emission mass flow rates from livestock barns). In: Emissionen der Tierhaltung (Emissions from Livestock 
Housing), KTBL-Script 449 (KTBL ed.), pp. 79-93, Darmstadt, Germany.

Ngwabie, N.M., K. H. Jeppsson, S. Nimmermark, C. Swensson and G. Gustafsson. 2009. Multi-location measurements of greenhouse gases and emission rates of methane and ammonia from a naturally-ventilated barn for dairy cows. Biosystems Engineering, (103):68-77.

Okuyama, H., Y. Onishi, S. I. Tanabe and S. Kashihara. 2009. Statistical data analysis method for multizonal airflow measurement using multiple kinds of perfluorocarbon tracer gas. Building and Environment, 44(3): 546-557.

Pereira, J., D. Fangueiro, T. Misselbrook, D. Chadwick, J. Coutinho and H. Trindade. 2011. Ammonia and greenhouse gas emissions from slatted and solid floors in dairy cattle houses: a scale model study. Biosystems Engineering, 109:148-157.

Reinhardt-Hanisch, A. 2008. Grundlagenuntersuchungen zur Wirkung neuartiger Ureaseinhibitoren in der Nutztierhaltung (Basic research on the effects of novel urease inhibitors in animal housing). PhD diss. Stuttgart, Germany: University of Hohenheim.

Samer, M. 2015. GHG Emission from Livestock Manure and its Mitigation Strategies. In: Climate Change Impact on Livestock: Adaptation and Mitigation, V. Sejian, J. Gaughan, L. Baumgard \& C. Prasad (Eds.), pp. 321-346, ISBN 978-81-322-2264-4, Springer International, Germany.

Samer, M. and M.E. Abuarab. 2014. Development of $\mathrm{CO}_{2}$-balance for ventilation rate measurements in naturally cross ventilated dairy barns. Transactions of the ASABE, Vol. 57(4): 1255-1264.

Samer, M. 2013. Emissions inventory of greenhouse gases and ammonia from livestock housing and manure management. Agricultural Engineering International: CIGR Journal, Vol. 15(3): 29-54.

Samer, M., W. Berg, H.-J. Müller, M. Fiedler, M. Gläser, C. Ammon, P. Sanftleben and R. Brunsch. 2011a. Radioactive ${ }^{85} \mathrm{Kr}$ and $\mathrm{CO}_{2}$-balance for ventilation rate measurements and gaseous emissions quantification through naturally ventilated barns. Transactions of the ASABE, 54(3):1137-1148.

Samer, M., C. Loebsin, M. Fiedler, C. Ammon, W. Berg, P. Sanftleben and R. Brunsch. 2011b. Heat balance and tracer gas 
technique for airflow rates measurement and gaseous emissions quantification in naturally ventilated livestock buildings. Energy and Buildings, Vol. 43(12): 3718-3728.

Samer, M., C. Loebsin, K. von Bobrutzki, M. Fiedler, C. Ammon, W. Berg, P. Sanftleben and R. Brunsch. 2011c. A computer program for monitoring and controlling ultrasonic anemometers for aerodynamic measurements in animal buildings. Computers and Electronics in Agriculture, Vol. 79(1): 1-12.

Schneider, B. 1988. Computer-based continuous recording of heat, water vapor, and carbon dioxide production in livestock barns. $\mathrm{PhD}$ diss. University of Hohenheim, Germany.

Schneider, F., R. Eichelser and S. Neser. 2006. Emissionen aus frei gelüfteten Ställen: Entwicklung von Messmethoden und Ergebnisse der Feldmessung (In German, Emissions from naturally ventilated barns: development of measurement methods and results of field measurement). Schriftenreihe der Bayerischen Landesanstalt für Landwirtschaft, 15: 145 - 157.

Seipelt, F. 1999. Quantifizierung und Bewertung gasförmiger Emissionen aus frei gelüfteten Milchviehställen mit Trauf-FirstLüftung (In German, Quantification and evaluation of gaseous emissions from naturally ventilated dairy barns with eaves-ridge ventilation). PhD Dissertation, University of Göttingen, Germany.

Schuurkes, J. and R. Mosello. 1988. The role of external ammonium inputs in freshwater acidification. Aquatic Sciences - Research Across Boundaries, 50(1): 71-86.

Sherman, M.H. 1989. On the estimation of multizone ventilation rates from tracer gas measurements. Building and Environment, 24(4): 355-362.

Sommer, S.G., S.O. Pedersen and H.T. Sogaard. 2000. Greenhouse gas emissions from stored livestock slurry. J. Environ. Qual. 29: 744-751.

Van Buggenhout, S., A. Van Brecht, S. Eren Ozcan, E. Vranken, W. Van Malcot and D. Berckmans. 2009. Influence of sampling positions on accuracy of tracer gas measurements in ventilated spaces. Biosystems Engineering, 104: 216-223. 
Von Bobrutzki K., H.-J. Müller and D. Scherer. 2011. Factors affecting the ammonia content in the air surrounding a broiler farm. Biosystems Engineering, 108:322-333.

Xin, H., H. Li, R.T. Burns, R.S. Gates, D.G. Overhults and J.W. Earnest. 2009. Use of $\mathrm{CO}_{2}$ concentration difference or $\mathrm{CO}_{2}$ balance to assess ventilation rate of broiler houses. Transactions of the ASABE, 52(4): 1353-1361.

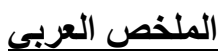

\section{التوزيع المكاني للتركيزات الاخلية للغاز ات الافيئة والأمونيا في مبنى لماشية}

\section{اللبن مهوى طبيعيا}

محمد سامر ' ، عصام عبد السلام ` ، جالا العزب ّ و خالد محمد عبد الباري'

تشكل مبان المانشية مصدر ا رئيسيا للانبعاثات الغازية مثل الأمونيا (NH3) وثاني أكسيد الكربون (N2O)

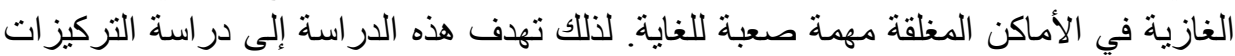
الداخلية لكل من NH3

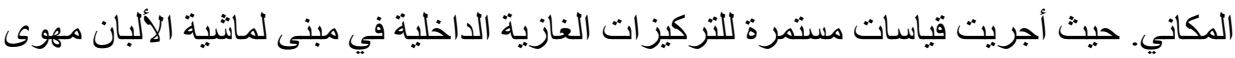

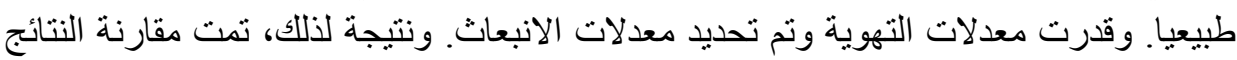

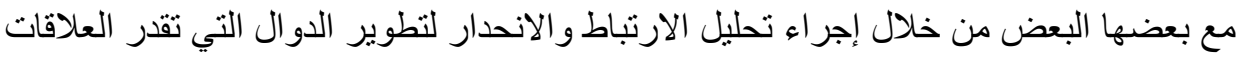

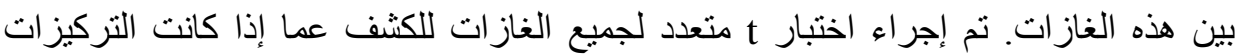

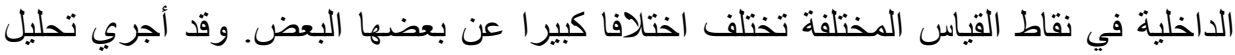

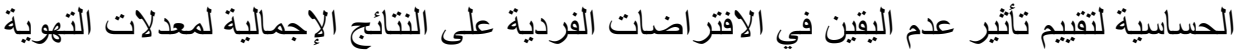

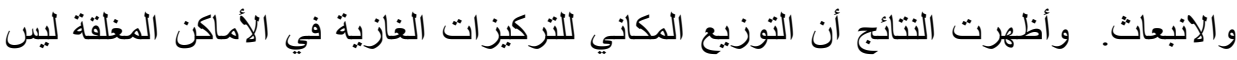

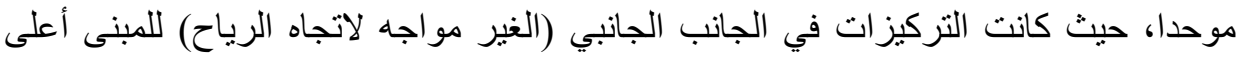

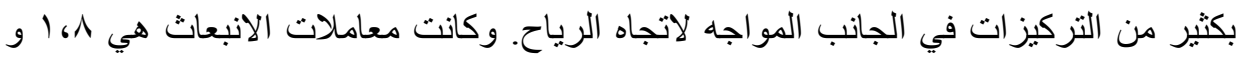

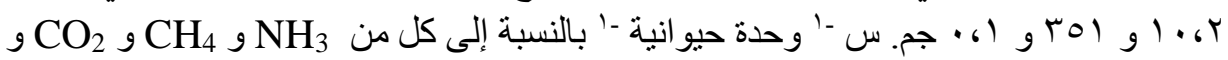
ع على النو الي.

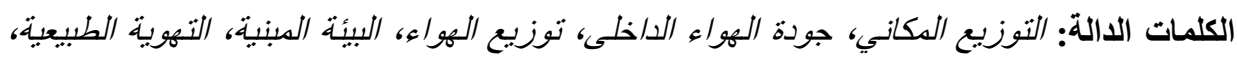
غازات الدفيئة، الأمونيا، مباني الماثية.

' أستاذ مساعد، قسم الهندسة الزراعية، قسم الهندسة الزراعية، كلية الزراعة الزئة ـ جامعة القاهرة.

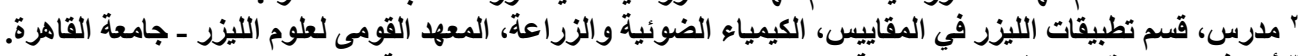

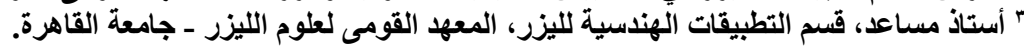

